\title{
Correction to: Soil biochemical properties and bacteria community in a repeatedly fumigated-incubated soil
}

\author{
Xiaoyu Zhou ${ }^{1,2} \cdot$ Lin Chen $^{3} \cdot$ Jianming Xu ${ }^{1,2} \cdot$ Philip C. Brookes ${ }^{1,2}$ (D) \\ Published online: 4 March 2020 \\ (C) Springer-Verlag GmbH Germany, part of Springer Nature 2020
}

\section{Correction to: Biology and Fertility of Soils} https://doi.org/10.1007/s00374-020-01437-0

The article "Soil biochemical properties and bacteria community in a repeatedly fumigated-incubated soil", written by Xiaoyu Zhou, Lin Chen, Jianming Xu, Philip C. Brookes, was originally published electronically on the publisher's internet portal (currently SpringerLink) on 05 February 2020 with open access. With the author(s)' decision to step back from Open Choice, the copyright of the article changed on 04 March 2020 to (C) Springer-Verlag GmbH Germany, part of Springer Nature 2020 and the article is forthwith distributed under the terms of copyright.

The original article has been corrected.

The online version of the original article can be found at https://doi.org/ $10.1007 / \mathrm{s} 00374-020-01437-0$

Philip C. Brookes

philip.brookes@rothamsted.ac.uk

1 Institute of Soil \& Water Resources and Environmental Science, College of Environmental and Resource Sciences, Zhejiang University, Hangzhou 310058, China

2 Zhejiang Provincial Key Laboratory of Agricultural Resources and Environment, Zhejiang University, Hangzhou 310058, China

3 State Key Laboratory of Soil and Sustainable Agriculture, Institute of Soil Science, Chinese Academy of Sciences, Nanjing 210008, China 